\title{
B7-H3 silencing by RNAi inhibits tumor progression and enhances chemosensitivity in U937 cells
}

\author{
This article was published in the following Dove Press journal: \\ OncoTargets and Therapy \\ 14 July 2015 \\ Number of times this article has been viewed
}

\section{Wei Zhang \\ Jing Wang \\ Yanfang Wang \\ Fei Dong \\ Mingxia Zhu \\ Wenli Wan \\ Haishen Li \\ Feifei Wu \\ Xinxing Yan \\ Xiaoyan Ke}

Department of Hematology and Lymphoma Research Center, Peking University Third Hospital, Beijing,

People's Republic of China
Correspondence: Xiaoyan Ke Department of Hematology and Lymphoma Research Center, Peking University Third Hospital, No 49 North Garden Road, Haidian District, Beijing I00191, People's Republic of China Tel +861082266780

Fax +8610 82266780

Email xykbysy@163.com
Background: The role of B7-H3 in acute monocytic leukemia U937 cells has not been thoroughly investigated.

Materials and methods: B7-H3 knockdown in the U937 cell line was performed using small hairpin (sh)RNA lentivirus transduction. The effects on cell proliferation, cycle, migration, and invasion were investigated by Cell Counting Kit- 8 assay, methyl cellulose colony-forming assay, propidium iodide staining, and Transwell assays in vitro. Changes in cell growth inhibition and apoptosis, when combined with chemotherapy drugs, were determined using the Cell Counting Kit-8 and Annexin V-FITC/PI assays. U937 xenograft models were used to assess the effects of B7-H3 on tumorigenicity and the therapeutic effect of B7-H3 knockdown in combination with chemotherapy drugs in vivo.

Results: Downregulation of B7-H3 significantly decreased U937 cell growth and colony-forming ability. The mean inhibition rate of tumor growth with B7-H3 knockdown was $59.4 \%$, and the expression of both Ki-67 and PCNA in xenografts was significantly reduced. After B7-H3 silencing, the U937 cell cycle was arrested at the G0/G1 phase. The cell migration rate of $\mathrm{B} 7-\mathrm{H} 3$ knockdown cells was reduced more than fivefold, and invasion capacity decreased by $86.7 \%$. B7-H3 RNAi profoundly increased the antitumor effect of chemotherapy in vitro and in vivo. On day 19, inhibition rates of tumor growth in B7-H3 shRNA combined with idarubicin, cytarabine, and idarubicin plus cytarabine were $70.5 \%, 80.0 \%$, and $90.0 \%$, respectively ( $P=0.006, P=0.004$, and $P=0.016$, respectively).

Conclusion: B7-H3 may promote U937 cell progression, and shRNA targeting B7-H3 significantly enhances sensitivity to chemotherapeutic drugs. These results may provide new insight into the function of B7-H3 and a promising therapeutic approach targeting B7-H3 in acute monocytic leukemia.

Keywords: B7-H3, acute monocytic leukemia, cancer gene therapy, chemosensitivity

\section{Background}

Acute monocytic leukemia (AML M5), a subtype of the acute myeloid leukemias (AML), comprises about $5 \%-10 \%$ of all AML cases. ${ }^{1}$ It is frequently associated with hyperleukocytosis, extramedullary involvement, coagulation disorders, and specific chromosomal abnormalities, which limit successful treatment. ${ }^{2}$ Characteristic 11 q23 translocations are commonly associated with AML M5 and are reported to predict a poor outcome. ${ }^{3}$ Although progress has been made in the management of AML M5 in the past decades, outcomes are still unsatisfactory. Therefore, understanding the molecular mechanisms of AML M5 pathogenesis and drug resistance will aid in the development of efficient treatments for the disease. 
B7-H3, a new member of the B7 family of immune-regulatory molecules, was identified in 2001 by database searches of a human dendritic cell-derived cDNA library. ${ }^{4}$ It is a type I transmembrane protein, which expresses in certain normal cells and tissues, such as dendritic cells, as well as the liver, lung, breast, placenta, and prostate..$^{5}$ Aberrant expression of B7-H3 has been reported in a wide range of solid cancers, including brain, lung, pancreatic, colorectal, liver, and breast cancers, ${ }^{6-11}$ as well as in hematologic malignancies, such as acute leukemia and multiple myeloma, ${ }^{12-14}$ and it is associated with more advanced disease and poor prognosis.

The function of B7-H3 remains contentious. Currently, nonimmunological functions of B7-H3 in cancer progression have received increasing attention, although its costimulatory ${ }^{4,5,15}$ or coinhibitory ${ }^{16-18}$ immune-regulatory effects on cellular and antitumor immune response were the focus of early studies. Using small interfering (si)RNA technology, Chen et al ${ }^{19}$ demonstrated that downregulation of human B7-H3 reduced cell adhesion to fibronectin, migration, and Matrigel invasion of melanoma and breast cancer cells. Other studies also reported that B7-H3 was important in regulating the adhesive, migratory, and invasive capacity in pancreatic cancer, prostate cancer, glioblastoma, cutaneous melanoma, and osteosarcoma. ${ }^{20-25}$ These studies suggest that B7-H3 may be a potential therapeutic target for tumors that overexpress it.

However, little is known about the direct impact of B7-H3 on tumor progression or B7-H3 RNA interference (RNAi)based targeting therapy in AML M5. In this study, we investigated the role of B7-H3 in AML M5 U937 cell proliferation, cycle, migration, and invasion. We also investigated whether B7-H3 has any impact on sensitivity to chemotherapy in vitro and in vivo.

\section{Materials and methods Cell line and cell culture}

Human AML M5 cell line U937 was obtained from the American Type Culture Collection (Manassas, VA, USA). The cells were cultured in Roswell Park Memorial Institute1640 (Gibco ${ }^{\circledR}$; Thermo Fisher Scientific, Waltham, MA, USA) medium containing $2 \mathrm{mM}$ L-glutamine, $100 \mathrm{U} / \mathrm{mL}$ penicillin, $100 \mu \mathrm{g} / \mathrm{mL}$ streptomycin, and $10 \%$ heat-inactivated fetal bovine serum (FBS) (HyClone; GE Healthcare Bio-Sciences Corp., Piscataway, NJ, USA), at $37^{\circ} \mathrm{C}$ in a $5 \% \mathrm{CO}_{2}$ incubator.

\section{Lentivirus-based RNA interference transfection and generation of stable cell lines}

The human B7-H3 (gene ID: 80381) targeting small hairpin (sh)RNA sequence 5'-TCGTGTGCTGGAGAAAGA
TCAAACAGAGC-3' and a negative nontargeted control sequence 5'-GCACTACCAGAGCTAACTCAGATAG TACT $-3^{\prime}$ were used to generate recombinant lentiviral particles. $^{23}$ This recombinant lentivirus was prepared and titered to $5 \times 10^{9}$ transfection units $/ \mathrm{mL}$, and the multiplicity of infection was 10 . Antibiotic-resistant clones were isolated and maintained in medium containing $250 \mu \mathrm{g} / \mathrm{mL}$ puromycin (Sigma-Aldrich Co., St Louis, MO, USA). Reverse transcription-polymerase chain reaction (RTPCR), Western blotting, and fluorescence-activated cell sorting (FACS) analysis were performed to confirm the knockdown of B7-H3. The transfected cells comprised the B7-H3 shRNA (KD) and negative nontargeted control (NC) groups, and the nontransfected cells were the control (CON) group. These three groups were used for the following experiments.

\section{Gene expression of B7-H3, RT-PCR, Western blotting and flow cytometry}

Total RNA was extracted and reverse transcribed to produce cDNA. The primers used for PCR were as follows: 5'-CTCTGCCTTCTCACCTCTTTG-3' (forward) and 5'-CCTTGAGGGAGGAACTTTATC-3' (reverse) for B7-H3 (134 bp); ${ }^{20}$ 5'-TTGACGGTAAGGACGGACTC-3' (forward) and 5'-ACTTGCAGTACTCCCCATCG-3' (reverse) for matrix metalloproteinase (MMP)-2 (153 bp); 5'-TTGACAGCGACAAGAAGTGG-3' (forward) and 5'-CCCTCAGTGAAGCGG TACAT-3' (reverse) for MMP-9 (148 bp); ${ }^{26}$ and 5'-TGACGTGGACATCCGCAAAG-3' (forward) and 5'-CTGGAAGGTGGACAGCGAGG-3' (reverse) for $\beta$-actin (205 bp). The PCR conditions were $94^{\circ} \mathrm{C}$ for 2 minutes, then 36 cycles or 28 cycles (B7-H3/ MMP-2/MMP-9: 36 cycles; $\beta$-actin: 28 cycles) at $94^{\circ} \mathrm{C}$ for 30 seconds, $56^{\circ} \mathrm{C}$ or $59^{\circ} \mathrm{C}$ (B7-H3: $56^{\circ} \mathrm{C}$; MMP-2/MMP$9 / \beta$-actin: $59^{\circ} \mathrm{C}$ ) for 30 seconds, $72^{\circ} \mathrm{C}$ for 30 seconds, and finally $72^{\circ} \mathrm{C}$ for 2 minutes.

The cells were lysed on ice, and the nuclear and cytoplasmic protein was extracted using Mammalian Protein Extraction Reagent (Changzhou ComWin Fine Chemicals Co., Ltd., Jiangsu, People's Republic of China). The concentration of protein was determined using the bicinchoninic acid (BCA) method. A total of $30 \mu \mathrm{g}$ of protein was transferred onto nitrocellulose filter membranes after 10\% SDS-PAGE. The membranes were blocked and incubated with primary antibodies, including rabbit anti-B7-H3 (1:500 dilution; 110 kDa) (clone EPNCIR122; Epitomics; Abcam plc, Cambridge, $\mathrm{UK}$ ) or mouse anti- $\beta$-actin (1:1,000 dilution; $43 \mathrm{kDa}$ ) (clone C-2; Santa Cruz, CA, USA) monoclonal antibodies overnight at $4{ }^{\circ} \mathrm{C}$. After incubation with IRDye $800 \mathrm{CW}$ conjugated 
goat (polyclonal) antirabbit/antimouse immunoglobulin $\mathrm{G}$ secondary antibody (1:10,000 dilution) (LI-COR Biosciences, Lincoln, NE, USA) for 1 hour, the fluorescent bands were visualized with an Odyssey infrared imaging system (LI-COR Biosciences), and the gray values were analyzed using the Odyssey V3.0 software.

Single-cell suspensions were stained with B7-H3 (CD276)-APC monoclonal antibody (clone 7-517; eBioscience, Inc., San Diego, CA, USA) on ice for 30 minutes. After three washes in phosphate buffered saline (PBS), the cells were analyzed using a flow cytometry system (FACSCalibur; BD Biosciences, San Jose, CA, USA). The isotype control antibody was from BD Biosciences.

\section{CCK-8 assay}

The Cell Counting Kit-8 (CCK-8) (Dojindo Laboratories, Kumamoto, Japan) was used to study the effect of B7-H3 shRNA on cell proliferation. Resuspended cells were plated at $1 \times 10^{5}$ cells/well in a 96 -well plate for 24 -hour, 48-hour, or 72 -hour inoculation. A volume of $10 \mu \mathrm{L} /$ well of CCK-8 solution was added into the plate. After incubation at $37^{\circ} \mathrm{C}$ for 4 hours, the absorbance was measured at $450 \mathrm{~nm}$ using a microplate reader. The inhibition rate of cell growth was as follows:

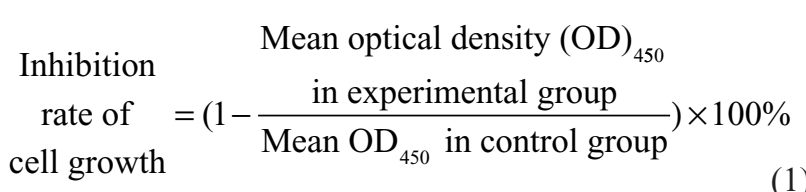

The assay was performed in sextuplicate for each group.

\section{Colony-forming assay}

A $5 \times 10^{3}$ single-cell suspension was resuspended in $1 \mathrm{~mL}$ medium with $20 \%$ FBS and $0.9 \%$ methyl cellulose (SigmaAldrich Co.). The samples were plated in 24-well plates and incubated for 14 days. A colony with more than 50 cells was counted as one positive colony.

$$
\begin{gathered}
\text { The colony- } \\
\text { forming } \\
\text { ability (CFA) }
\end{gathered}=\frac{\begin{array}{c}
\text { Colony counts in } \\
\text { experiment group }
\end{array}}{\text { Colony counts in control group }} \times 100 \%
$$

Each experiment was repeated three times.

\section{Subcutaneous xenograft model and tumorigenicity assay}

Female BALB/c nude mice, 5-6 weeks of age, and weighing 16-18 g (Experimental Animal Center, Peking
University Health Science Center, Beijing, People's Republic of China), were bred under specified pathogenfree conditions. All of the care, experimental procedures, and handling of animals were performed with approval of the Institutional Authority for Laboratory Animal Care of Peking University. Mice were pretreated by intraperitoneal injection, with $100 \mathrm{mg} / \mathrm{kg}$ cyclophosphamide (Jiangsu Hengrui Medicine Co., Ltd., Shanghai, People's Republic of China) dissolved in normal saline (NS) once daily for two consecutive days, in order to increase the rate of tumor formation. The next day, $1 \times 10^{7}$ cells (U937 cells in the $\mathrm{CON}, \mathrm{NC}$, or $\mathrm{KD}$ group, six mice per group) in 100 $\mu \mathrm{L}$ NS were injected subcutaneously into the right axilla region of the nude mice.

The xenografted tumor volume (V) was measured every other day and calculated as:

$$
\mathrm{V}\left(\mathrm{mm}^{3}\right)=\text { length } \times \text { width }^{2} \times 0.5
$$

The inhibition rate of tumor growth was calculated using the formula:

$$
\begin{gathered}
\text { Inhibition rate of } \\
\text { tumor growth }
\end{gathered}=\left(1-\frac{\begin{array}{c}
\text { Average tumor weight } \\
\text { of treated group }
\end{array}}{\begin{array}{c}
\text { Average tumor weight } \\
\text { of control group }
\end{array}}\right) \times 100 \%
$$

\section{Immunohistochemical analysis}

At the end of the observation (19 days postinoculation), the xenograft tumors in the three groups were excised and fixed in $10 \%$ neutrally buffered formalin for 24 hours. After they were embedded in paraffin, deparaffinized, and rehydrated, the histologic sections were subjected to heat-induced epitope retrieval in a microwave oven in $1 \mathrm{mmol} / \mathrm{L}$ EDTA buffer ( $\mathrm{pH}$ 8.0) and quenched for endogenous peroxidase activity with $3 \%$ hydrogen peroxide. Then, the sections were stained with a rabbit polyclonal antibody to the cell proliferation-associated antigen Ki-67 (1:500 dilution) or a mouse monoclonal antibody to proliferating cell nuclear antigen (PCNA) (1:300 dilution) (Dako Corporation, Copenhagen, Denmark), respectively, followed by incubation with the secondary antibody (Dako Denmark A/S, Glostrup, Denmark) using the avidin-biotin-peroxidase method. PBS was used as a negative control. After incubation with 3,3'-diaminobenzidine and counterstaining with hematoxylin, the sections were analyzed in five randomly selected microscopic fields $(400 \times)$. The Ki-67 labeling index, or the positive expression rate of PCNA, was calculated as follows: 


$$
\begin{gathered}
\text { Ki-67 labeling index } \\
\text { or positive expression } \\
\text { rate of PCNA }
\end{gathered}=\frac{\begin{array}{c}
\text { Positively stained } \\
\text { cells counts }
\end{array}}{\begin{array}{c}
\text { Total number of } \\
\text { nucleated cells }
\end{array}} \times 100 \%
$$

\section{Cell cycle analysis}

The cells in each group were collected, washed with PBS, and fixed in $70 \%$ ethanol overnight at $-20^{\circ} \mathrm{C}$. The cellular DNA was stained with propidium iodide $(500 \mu \mathrm{g} / \mathrm{mL})$ (Beijing Biosea Biotech Co., Ltd., Beijing, People's Republic of China) $\left(10 \mu \mathrm{L} / 10^{5}\right.$ cells $)$ for 10 minutes at room temperature. The DNA content and cell number were determined by FACS analysis, and cell cycle profiles were analyzed using the ModFit program (Verify Software House, Inc.). The proliferation index (PI) was calculated using the following equation:

$$
P I=\left[\frac{(S+G 2 M)}{(G 0 / G 1+S+G 2 M)}\right] \times 100 \%
$$

Each experiment was repeated three times.

\section{Cell migration and invasion assay}

For the in vitro migration and invasion assays, $5 \times 10^{5}$ cells or $2 \times 10^{5}$ cells were resuspended in serum-free medium and placed on top of $8 \mu \mathrm{m}$ pore-size Transwell chambers (8.0 $\mu \mathrm{m}$ PC; Corning Incorporated, Corning, NY, USA) or Matrigel (1:5 dilution) (BD Biosciences) invasion chambers. The lower chambers contained medium with $10 \%$ FBS. After 24 hours of incubation, the migrating cells in the lower chamber or invading cells on the bottom of each well were stained with 4',6-diamidino-2-phenylindole ( $1 \mathrm{mg} / \mathrm{mL}$; Beijing Solarbio Science \& Technology Co., Ltd., Beijing, People's Republic of China) or $0.1 \%$ crystal violet followed by fixation in methyl alcohol for 30 minutes. Then, the number of cells in six randomly selected microscopic fields $(200 \times)$ was counted with a BX51 fluorescence microscope (Olympus Corporation, Tokyo, Japan) or a DM IL inverted phase microscope (Leica Microsystems, Wetzlar, Germany).

$$
\begin{gathered}
\text { The migration } \\
\text { rate }
\end{gathered}=\frac{\begin{array}{c}
\text { Cell count in the } \\
\text { lower chamber }
\end{array}}{\text { The total number on the }} \times 100 \%
$$

MMP-2 and MMP-9 were detected by RT-PCR to further determine the ability of tumor cells to penetrate the cell matrix. Each experiment was repeated three times.

\section{Analysis of drug-induced cytotoxicity and apoptosis}

Idarubicin (IDA) $(6.25 \mathrm{nmol} / \mathrm{L}, 12.5 \mathrm{nmol} / \mathrm{L}, 25 \mathrm{nmol} / \mathrm{L}$, $50 \mathrm{nmol} / \mathrm{L}, 100 \mathrm{nmol} / \mathrm{L}, 200 \mathrm{nmol} / \mathrm{L}, 400 \mathrm{nmol} / \mathrm{L}, 800 \mathrm{nmol} / \mathrm{L}$, and 1,000 nmol/L) (Zavedos; Actavis Italy S.p.A., Milan, Italy) or cytarabine (Ara-C) $(6.25 \mathrm{nmol} / \mathrm{L}, 12.5 \mathrm{nmol} / \mathrm{L}$, $25 \mathrm{nmol} / \mathrm{L}, 50 \mathrm{nmol} / \mathrm{L}, 100 \mathrm{nmol} / \mathrm{L}, 200 \mathrm{nmol} / \mathrm{L}$, $400 \mathrm{nmol} / \mathrm{L}, 800 \mathrm{nmol} / \mathrm{L}$, and 1,000 nmol/L) (Cytosar; Actavis Italy S.p.A.) was added to the three groups of U937 cells for 24 hours, 48 hours, or 72 hours, and then absorbance was detected using the $\mathrm{CCK}-8$ reagent to evaluate the effect of cell proliferation inhibition by the chemotherapy drugs.

Resuspended cells $\left(1 \times 10^{6}\right.$ cells/well $)$ in each group were grown in triplicate in six-well plates with $50 \mathrm{nmol} / \mathrm{L}$ IDA and/or $50 \mathrm{nmol} / \mathrm{L}$ Ara-C for 12 hours and 24 hours. A volume of $10 \mu \mathrm{L}$ Annexin V-fluorescein isothiocyanate $(20 \mu \mathrm{g} / \mathrm{mL})$ (Biosea) was added to the collected cells. After incubation for 15 minutes at room temperature, $300 \mu \mathrm{L}$ of binding buffer was added. Then, we added $10 \mu \mathrm{L}$ of propidium iodide $(50 \mu \mathrm{g} / \mathrm{mL})$ (Biosea) to the mixtures. The cell samples were assessed by flow cytometry within 1 hour. The CellQuest software (BD, Franklin Lakes, NJ, USA) was used for data acquisition and analysis.

\section{Caspase- 3 assay}

We initially treated U937 cells $\left(5 \times 10^{6}\right.$ cells/dish) with $50 \mathrm{nmol} / \mathrm{L}$ IDA and/or $50 \mathrm{nmol} / \mathrm{L}$ Ara-C for 0 hours and 12 hours. The cells were then collected and lysed on ice for 1 hour. The concentration of protein was detected using the BCA method. A total of $150 \mu \mathrm{g}$ of protein was detected using the caspase-3 Colorimetric Assay Kit (Nanjing KeyGen Biotech Co., Ltd., Nanjing, People's Republic of China).

$\begin{gathered}\text { The activity of } \\ \text { caspase- } 3\end{gathered}=\frac{\mathrm{OD}_{405} \text { in the experiment group }}{\mathrm{OD}_{405} \text { in the control group }}$

\section{The effect of B7-H3 RNAi on chemosensitivity in vivo}

A mouse bearing noninfected U937 cell xenograft model was established, as described earlier. When tumors had reached an average volume of $100 \mathrm{~mm}^{3} 7$ days after inoculation, the treatments began, followed by the tumor-bearing mice being allocated randomly into ten groups (six mice per group) that included: 1) an equal volume of NS injection; 2) IDA $(3 \mathrm{mg} / \mathrm{kg}$ ) treatment; 3 ) negative nontargeted control plasmid 
$(\mathrm{pNC})+$ IDA (3 mg/kg) treatment; 4) shRNAs targeting B7-H3 plasmid (pKD) + IDA (3 mg/kg) treatment; 5) Ara-C $(30 \mathrm{mg} / \mathrm{kg})$ treatment; 6) $\mathrm{pNC}+\mathrm{Ara}-\mathrm{C}(30 \mathrm{mg} / \mathrm{kg})$ treatment; 7) $\mathrm{pKD}+$ Ara-C (30 mg/kg) treatment; 8) IDA (3 mg/kg) + Ara-C $(30 \mathrm{mg} / \mathrm{kg})$ treatment; 9) $\mathrm{pNC}+\mathrm{IDA}(3 \mathrm{mg} / \mathrm{kg})+$ Ara-C (30 mg/kg) treatment; and 10) pKD + IDA (3 mg/kg) + Ara-C $(30 \mathrm{mg} / \mathrm{kg})$ treatment. The chemotherapy drugs and NS were administered intraperitoneally, while the mixture of plasmid DNA (10 $\mu \mathrm{g}$ pNC or pKD) and lipofectamine 2000 (30 $\mu \mathrm{L}$; Thermo Fisher Scientific) in $50 \mu \mathrm{L}$ NS were intratumorally injected. All of the treatments were performed every other day, for a total of five treatments. Tumor volume, tumor weight, and mouse weight were measured.

\section{Statistical analysis}

The data are shown as the mean \pm standard deviation of triplicate values for each experiment. Statistical comparisons were performed using analysis of variance. A value of $P<0.05$ was considered statistically significant. The statistical analysis was performed using the SPSS 18.0 software (IBM Corporation, Armonk, NY, USA).

\section{Results}

\section{B7-H3 stably silenced U937 cell line generation}

The U937 cells highly expressed B7-H3 both in mRNA and protein levels by RT-PCR, Western blotting, and FACS (Figure 1; the CON group). B7-H3 knockdown in U937 cells was performed using lentivirus transduction to stably express shRNA targeting B7-H3. There was no significant difference in B7-H3 expression between the parental noninfection (CON) cells and the NC by RT-PCR, Western blotting, and FACS $(P>0.05)$. The B7-H3 expression in the KD cells was decreased compared to the NC group $(P<0.05)$. The mean inhibition rates of B7-H3 expression in terms of abundance of mRNA, nuclear and cytoplasmic protein, and membrane protein levels were $78.9 \%, 69.2 \%$, and $95.5 \%$, respectively (Figure 1). These show that the knockdown of B7-H3 in U937 cells by RNAi was specific and efficient.

\section{B7-H3 knockdown inhibits tumor proliferation in vitro and in vivo}

We used CCK-8 and colony-forming assays to evaluate the effects of B7-H3 knockdown on tumor cell proliferation in vitro. The stable knockdown of B7-H3 in U937 cells significantly reduced cell growth. Compared to the NC group, the growth of KD cells was decreased by $32.8 \%$ after 72 hours
A

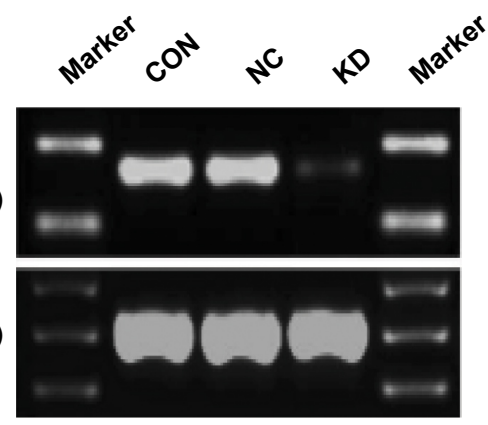

$\begin{array}{llll}\text { B } & \text { CON NC } & \text { KD }\end{array}$

B7-H3 (134 bp)

$\beta$-actin (205 bp)

B7-H3 (110 kDa)

$\beta$-actin (43 kDa)
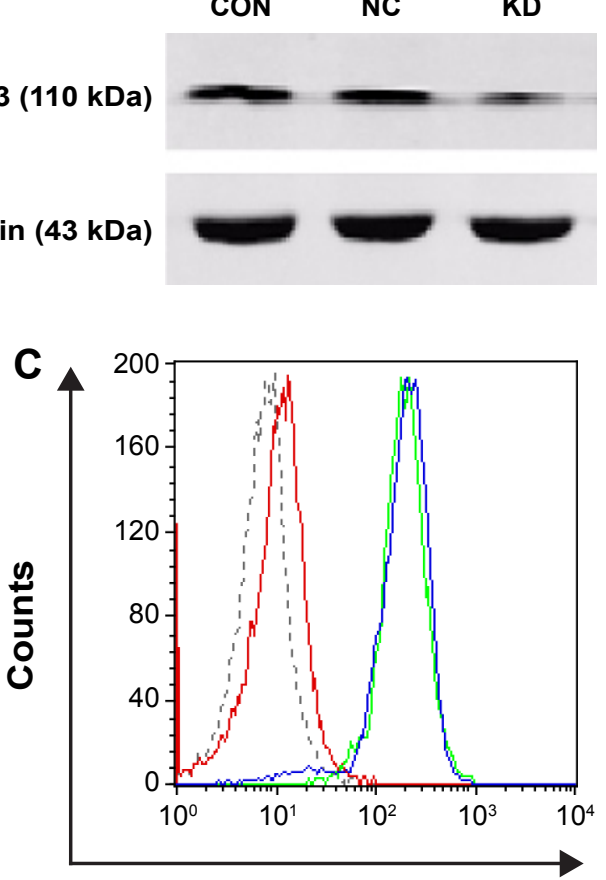

B7-H3

Figure I The effect of silencing B7-H3 by shRNA in U937 cells.

Notes: (A) B7-H3 mRNA knockdown was shown by RT-PCR. (B) B7-H3 nuclear and cytoplasmic protein was knocked down, as determined by Western blotting evaluation with the gray values of $\mathrm{B} 7-\mathrm{H} 3 /$ the gray values of $\beta$-actin in each group. $\beta$-actin was probed as a positive control. (C) B7-H3 membrane protein expression was determined by FACS and calculated by the positive expression rates, gating with the isotype controls. The blue line represents the CON group, the green line is the NC group, the red line is the KD group, and the gray line is the isotype control. The data are from at least three separate experiments.

Abbreviations: CON, control group of nontransfected cells; NC, transfected group with negative nontargeted control sequence; $K D$, transfected group with $B 7-$ H3 small hairpin RNA; shRNA, small hairpin RNA; mRNA, messenger RNA; RT$\mathrm{PCR}$, reverse transcription polymerase chain reaction; FACS, fluorescence-activated cell sorting.

of incubation $(P=0.017$ ) (Figure $2 \mathrm{~A})$. The colony formation assay further confirmed that B7-H3 silencing inhibits U937 cell proliferation. After 14 days of incubation, the average CFA of KD cells was $22.5 \%$ compared with $92.8 \%$ in the NC group $(P=0.000)$ (Figure $2 \mathrm{~B}$ and $\mathrm{C}$ ).

To detect the in vivo effect of B7-H3 knockdown on tumorigenicity, we established xenograft models by subcutaneously injecting U937 cells into the right axilla 
A

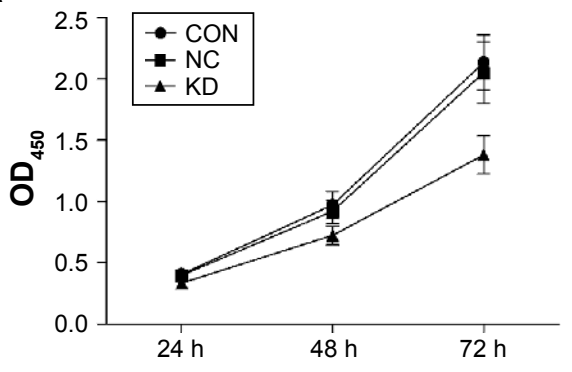

B

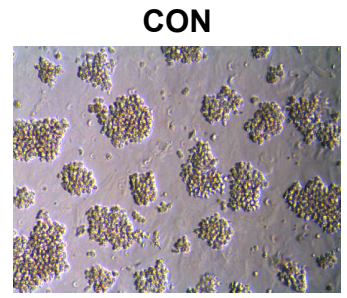

D

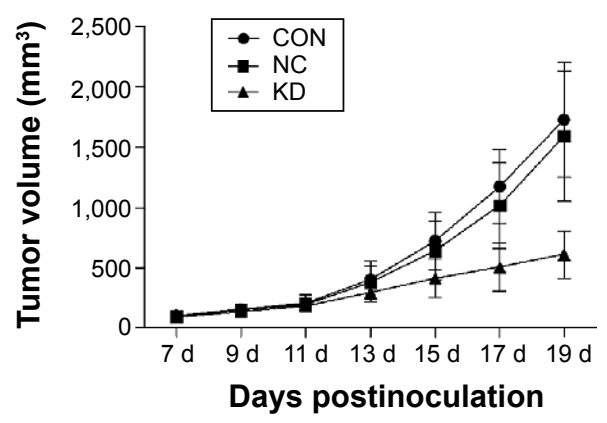

C

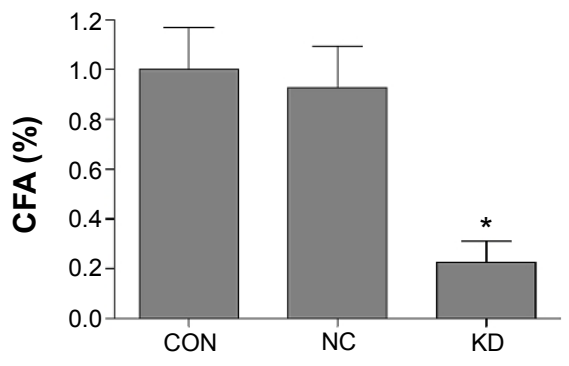

NC

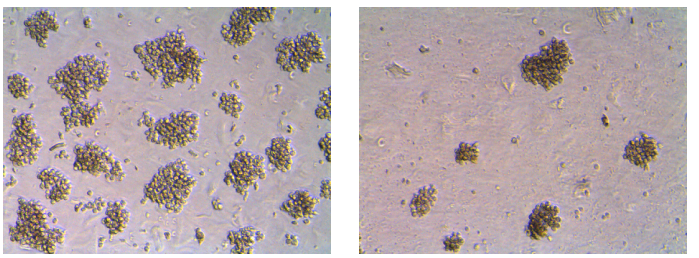

E

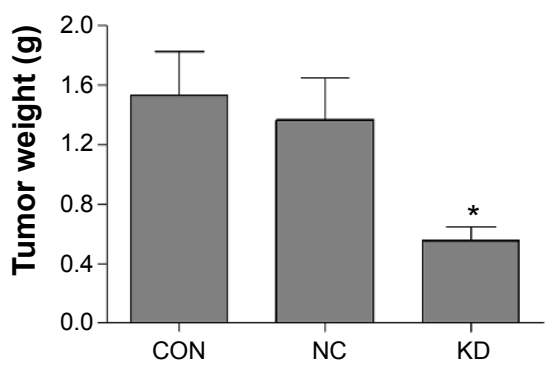

$\mathbf{F}$

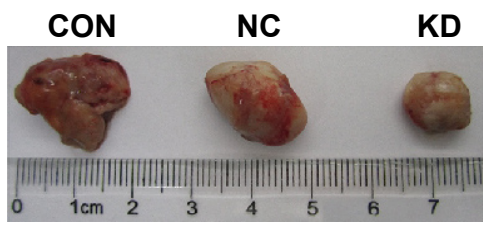

G

CON

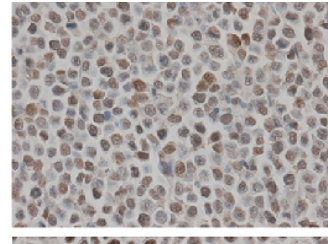

NC

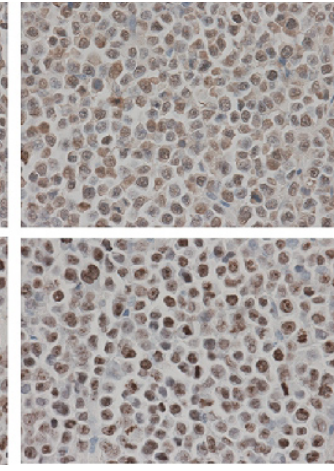

KD

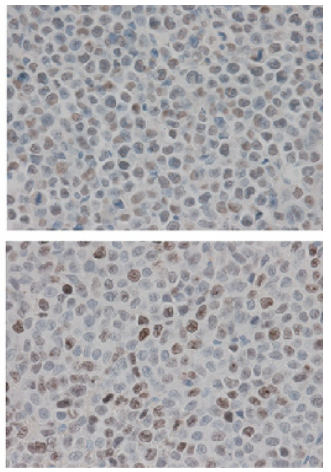

Figure 2 B7-H3 knockdown inhibits tumor proliferation in vitro and in vivo.

Notes: (A) B7-H3 silencing inhibited cell growth analyzed by CCK-8 assay. (B and C) B7-H3 knockdown inhibited the colony formation detected by methyl cellulose colony-forming assay $(\times 100)$. The data are from at least three separate experiments. (D) Silencing of B7-H3 significantly inhibited tumor growth in vivo compared with the NC. (E) Tumor weight of the B7-H3 KD group was decreased compared to the NC group on day 19. (F) Excised xenograft tumors on day I9. (G) Immunohistochemical staining of Ki-67 and PCNA for proliferative cells in a B7-H3 knockdown xenograft was reduced compared to the NC group on day 19 ( $\times 400)$. *Indicates that the results are statistically significant compared to the NC group; $P<0.05$.

Abbreviations: $\mathrm{CON}$, control group of nontransfected cells; NC, transfected group with negative nontargeted control sequence; KD, transfected group with B7-H3 small hairpin RNA; h, hours; d, days; CCK-8, Cell Counting Kit-8; PCNA, proliferating cell nuclear antigen; CFA, colony-forming ability. 
region of $\mathrm{BALB} / \mathrm{c}$ nude mice. All of the 18 mice in the three groups developed detectable tumor nodules 7 days after inoculation. The increase in tumor volume in the B7-H3 silencing group was slowed down compared to the NC group injected with nontargeted sequence transfected cells, while no significant difference was observed between the NC group and the nontransfection group $(P>0.05)$ (Figure 2D). At the end of the observation period (19 days), the mean inhibition rate of tumor growth with B7-H3 knockdown was $59.4 \%(P=0.009)$ (Figure $2 \mathrm{E}$ and $\mathrm{F})$. Furthermore, we assessed two markers reflecting tumor cell proliferation activity, Ki-67 and PCNA, through immunohistochemical staining. Apparently fewer cells were stained in the B7-H3 KD group than in the NC group, both for Ki-67 and PCNA. The Ki-67 labeling index of the excised xenograft tumors in the B7-H3 KD group was $37.7 \% \pm 5.0 \%$, which was significantly lower than in the NC group at $77.4 \% \pm 7.9 \%$ $(P=0.002)$. The B7-H3 knockdown also decreased the positive expression rate of PCNA compared with the NC group (35.7\% $\pm 4.6 \%$ versus $75.6 \% \pm 5.8 \%$, respectively) $(P=0.001)$ (Figure 2G).

\section{B7-H3 knockdown arrests U937 cell cycle at the G0/GI phase}

To determine whether B7-H3 expression affects cell cycle progression, we used flow cytometry to compare the G0/G1, $\mathrm{S}$, and $\mathrm{G} 2 / \mathrm{M}$ phases. Figure $3 \mathrm{~A}$ and $\mathrm{B}$ show that the U937 cell cycle progression was inhibited after B7-H3 silencing. The average PI was decreased by $14.27 \%$ in the KD group compared to the NC group (36.17\% versus $50.44 \%$, respectively) $(P=0.004)$. This suggests that the knockdown of B7-H3 arrests U937 cell cycle at the G0/G1 phase to inhibit cell proliferation activity.

\section{B7-H3 knockdown inhibits U937 cell migration and invasion}

To investigate whether $\mathrm{B} 7-\mathrm{H} 3$ acts as a tumor migration and invasion regulator, we used Transwell migration and invasion assays to compare the cell migration rate and invasive capacity in each group. Figure 4A and B show that the migration rate of the KD cells to the lower chamber was significantly reduced after 24 hours of incubation compared to the NC group, with a $8.6 \%$ versus $44.2 \%$ reduction, respectively, which is more than fivefold lower $(P=0.000)$. In addition, the invasive capacity of KD cells was reduced by $86.7 \%$ compared to the NC group, with 18 cells versus 138 cells per six random microscopic fields $(P=0.000)$ (Figure $4 \mathrm{C}$ and D). Both the cell migratory and invasive potential in the
$\mathrm{CON}$ and NC group were similar $(P>0.05)$. Furthermore, we measured the invasion-related proteins by RT-PCR and found that MMP-2 and MMP-9 were lower in the KD cells than in the NC group (Figure 4E). These results indicate that silencing B7-H3 can impede cell migration and inhibit cell invasion via downregulating the expression of MMP-2 and MMP-9.

\section{B7-H3 knockdown enhances drug-induced cytotoxicity and apoptosis in vitro}

We selected the first-line chemotherapy drugs used in AML M5, IDA and Ara-C, to study the effects of B7-H3 knockdown on chemotherapeutic drug-induced cytotoxicity and apoptosis. Following treatment with various concentrations of IDA or Ara-C for 24 hours, 48 hours, or 72 hours, a dose-dependent and time-dependent inhibition of cell growth was observed in each group using the CCK-8 assay (data not shown). Concentrations of $50 \mathrm{nmol} / \mathrm{L}$ IDA and/or $50 \mathrm{nmol} / \mathrm{L}$ Ara-C were selected for the three groups of U937 cells, and the absorbance was compared (Figure 5A). The cell survival rates in the KD group were significantly decreased compared to those of the NC group combined with the same chemotherapy $(P<0.05)$, and the two-drug combinations synergistically inhibited $\mathrm{KD}$ cell proliferation compared to the single-drug groups.

Exposure to $50 \mathrm{nmol} / \mathrm{L}$ IDA and/or $50 \mathrm{nmol} / \mathrm{L}$ Ara-C for 12 hours and 24 hours suggested that B7-H3 silencing promoted apoptosis in U937 cells in a time-dependent manner, and the apoptosis rates of KD cells were the most significantly increased in the two-drug combination groups $(64.48 \% \pm 4.72 \%$ for 12 hours and $85.06 \% \pm 5.31 \%$ for 24 hours, versus $39.68 \% \pm 2.62 \%$ and $63.10 \% \pm 2.69 \%$, respectively) ( $P=0.023$ and $P=0.035$ ) (Figure 5B and $\mathrm{C}$ ). After exposure to IDA and/or Ara-C for 12 hours, we measured the activity of the apoptosis-related protein caspase- 3 . The results demonstrated that the activity of caspase- 3 in the KD group compared to the $\mathrm{NC}$ group was significantly increased with IDA, Ara-C, and IDA + Ara-C (3.28 $\pm 0.13,2.81 \pm 0.14$, and $4.54 \pm 0.54$ versus $1.34 \pm 0.07,1.05 \pm 0.14$, and $2.78 \pm 0.29$, respectively) $(P=0.003, P=0.006$, and $P=0.003$ ) (Figure 5D). These results indicate that silencing B7-H3 increases druginduced cytotoxicity and promotes drug-mediated apoptosis by increasing the caspase- 3 activity in vitro.

\section{B7-H3 knockdown increases chemosensitivity in a xenograft model}

In order to explore the impact of B7-H3 knockdown on the antitumor activity of chemotherapy drugs in vivo, we 

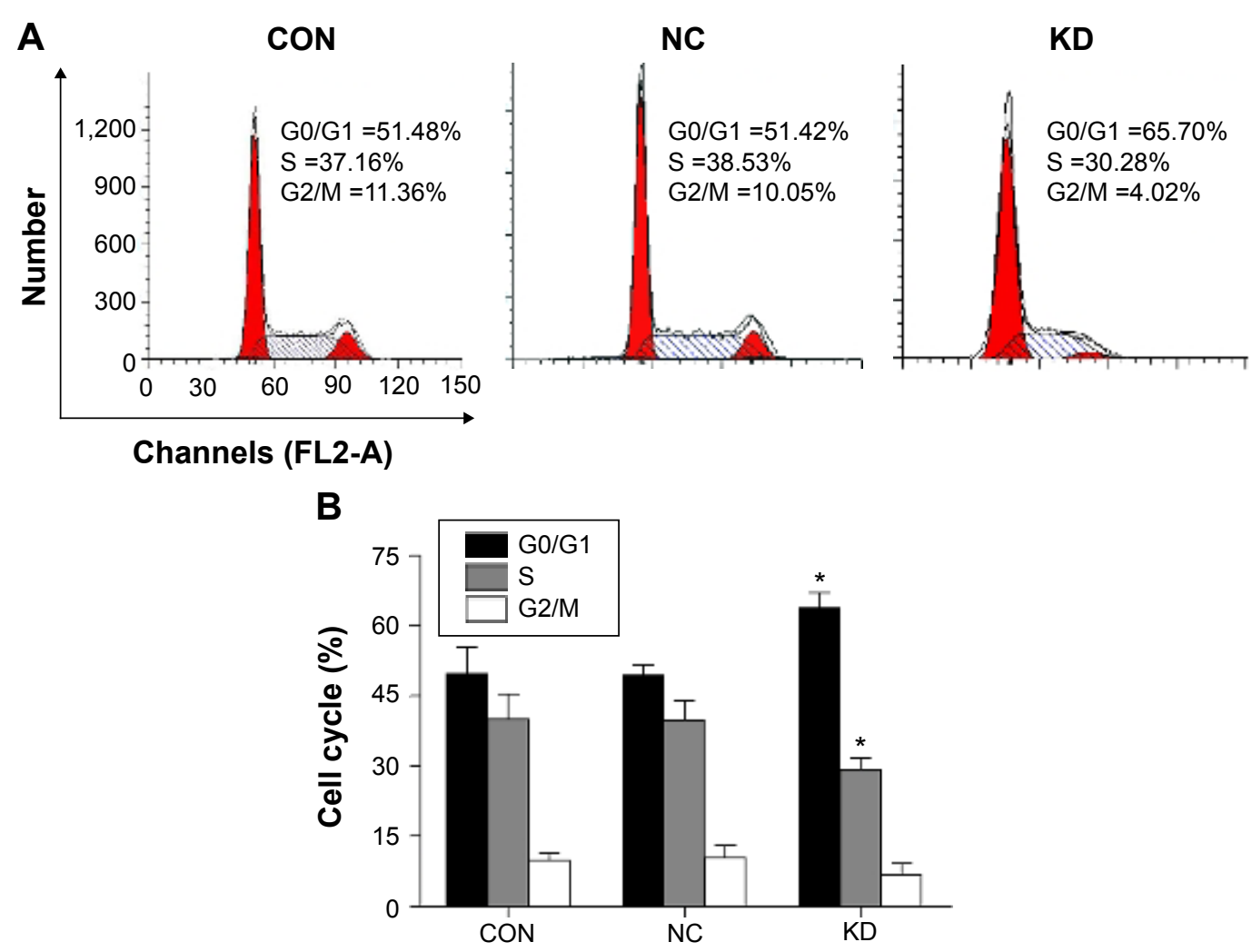

Figure 3 B7-H3 knockdown inhibits cell cycle progression.

Notes: (A and B) B7-H3 knockdown arrested the U937 cell cycle at the G0/GI phase, analyzed by FACS. *Indicates that the results are statistically significant compared to the NC group; $P<0.05$. The data are from at least three separate experiments.

Abbreviations: CON, control group of nontransfected cells; NC, transfected group with negative nontargeted control sequence; KD, transfected group with B7-H3 small hairpin RNA; FACS, fluorescence-activated cell sorting.

constructed a tumor-bearing mouse model injected with nontransfected U937 cells. The treatments began on day 7 , when the average tumor volumes reached $100 \mathrm{~mm}^{3}$. As shown in Figure 6A, the plasmid of B7-H3 shRNA (pKD) combined with IDA and/or Ara-C was more effective in reducing the established U937 tumor growth compared to the $\mathrm{pNC}$ groups combined with chemotherapy, while there were no significant differences in the tumor volumes between the $\mathrm{pNC}$ combined with chemotherapy groups and the chemotherapy groups alone. On day 19, the rates of tumor growth inhibition in B7-H3 shRNA combined with the IDA, Ara-C, and IDA + Ara-C groups were $70.5 \%, 80.0 \%$, and $90.0 \%$, respectively, which were higher than in the relative control plasmid combined with chemotherapy groups at 39.2\%, 44.0\%, and $73.9 \%$ ( $P=0.006, P=0.004$, and $P=0.016$, respectively) (Figure 6B and C). The B7-H3 shRNA combined with IDA $(3 \mathrm{mg} / \mathrm{kg})$ and Ara-C (30 mg/kg) treatment group exhibited the best antitumor activity. Furthermore, all mice treated with B7-H3 shRNA (group 4), 7), and 10) of ten tumor-bearing mice groups, as described earlier) exhibited no body weight loss at the end of our experiment on day 19 compared with the mice treated with pNC treatments (group 3), 6), and 9) of ten tumor-bearing mice groups, as described earlier) (Figure 6D). These results indicate that B7-H3 silencing can apparently enhance the chemosensitivity of U937 cells in a xenograft model.

\section{Discussion}

In the present study, we firstly generated and confirmed the U937 cells with targeted B7-H3 knockdown using lentivirus transduction. B7-H3 expression abundance was decreased at both the mRNA and protein level, with protein subcellular distribution in nuclei and cytoplasm, and membrane. The membrane protein was significantly inhibited by $95.5 \%$, higher than the rate of $79.4 \%$ in a recent study, ${ }^{20}$ which also used RNAi technology to knock down B7-H3 in pancreatic cancer Patu8988 cells. Therefore, the B7-H3 knockdown was specific and efficient, and this U937 cell model may be used for subsequent assays.

Previous studies found that the silencing of B7-H3 did not affect pancreatic and prostate cancer cell proliferation, ${ }^{20,21}$ and it moderately reduced $(20 \% \sim 30 \%)$ the growth of melanoma 

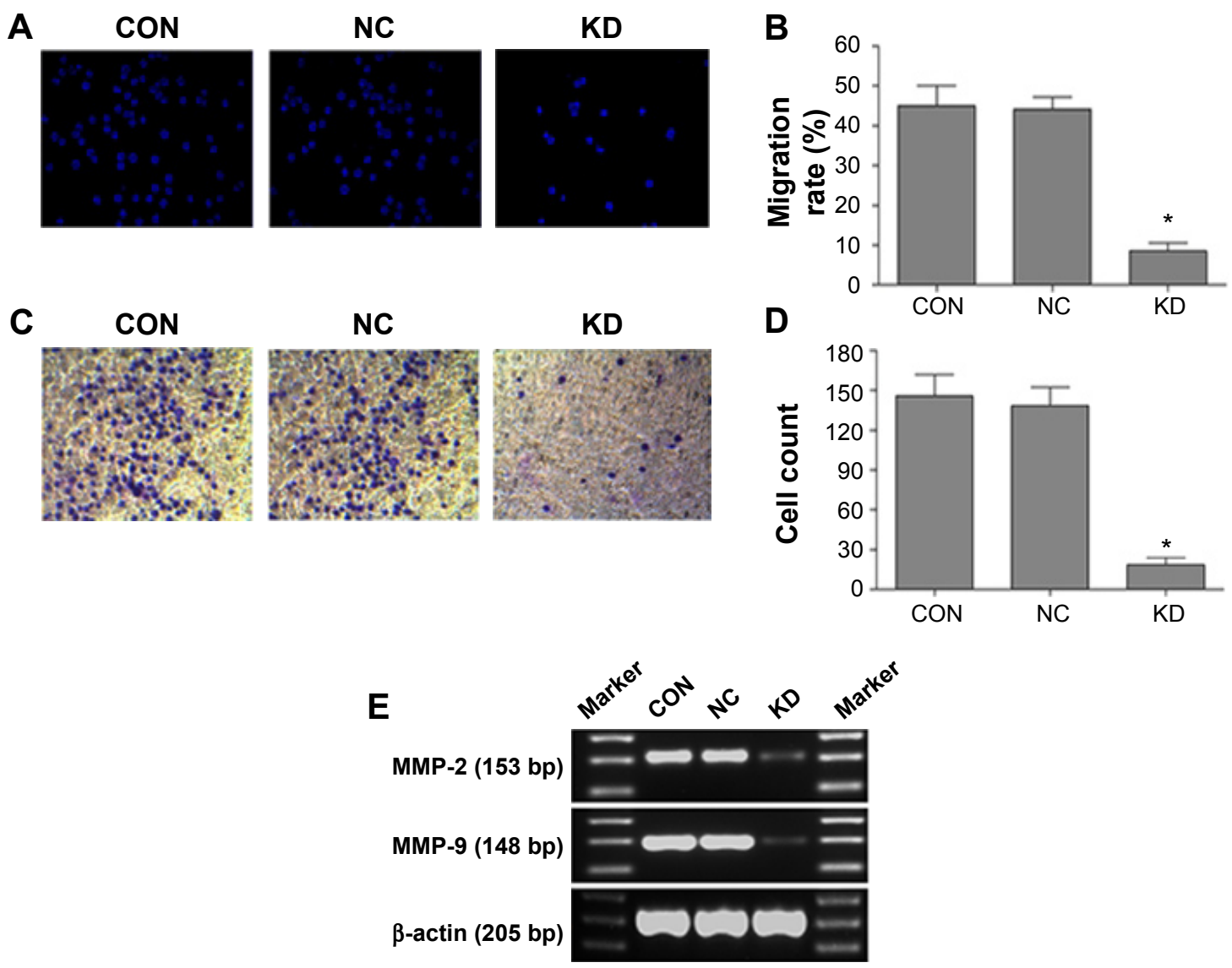

Figure 4 B7-H3 knockdown inhibits tumor migration and invasion.

Notes: (A and B) B7-H3 knockdown inhibited tumor migration to the lower chamber $(\times 200)$. (C and D) B7-H3 knockdown inhibited tumor invasion capacity $(\times 200)$. (E) Expression of invasion-related proteins MMP-2 and MMP-9 was lower in B7-H3-silenced cells, monitored by RT-PCR. *Indicates that the results are statistically significant compared to the NC group; $P<0.05$. The data are from at least three separate experiments.

Abbreviations: CON, control group of nontransfected cells; NC, transfected group with negative nontargeted control sequence; KD, transfected group with B7-H3 small hairpin RNA; MMP, matrix metalloproteinase; RT-PCR, reverse transcription polymerase chain reaction.

cells in vitro. ${ }^{23}$ Interestingly, we found that artificial silencing of B7-H3 significantly inhibited tumor growth by $32.8 \%$ compared to the NC cells in 72 hours, and inhibited the CFA by $70.3 \%$ after 14 days of incubation. Moreover, another in vitro experiment by our research team showed that B7-H3 knockdown decreased the growth of mantle cell lymphoma Maver and Z138 cells by $41.7 \%$ and $37.5 \%$, and declined the CFA by $71.2 \%$ and $77.2 \%$, respectively. ${ }^{27}$ The different effects of B7-H3 may depend on the various tumor types. Then, we established xenograft models to study the in vivo effect of B7-H3 knockdown on tumor growth. The growth of established B7-H3 knockdown xenografts was slowed down compared with the $\mathrm{NC}$ and the nontransfected control groups. The inhibition rate of tumor growth with B7-H3 knockdown was $59.4 \%$ at the end of the observation. Similar growth inhibition of B7-H3-knockdown xenografts in pancreatic, glioma, and breast cancers has been observed in other studies. $^{20,22,28}$ Subsequently, we found that the Ki-67 labeling indices and the positive expression rates of PCNA were significantly decreased in the B7-H3 silenced xenografts. Moreover, the average PI in KD cells was significantly decreased by $14.27 \%$, suggesting that the B7-H3 knockdown arrests the cell cycle at the G0/G1 phase to inhibit cell proliferation activity. Clearly, the in vivo results confirmed our in vitro observations, and the aforementioned data indicate that B7-H3 knockdown can inhibit AML M5 U937 cell proliferation through suppressing cell cycle progression and reducing the expression of $\mathrm{Ki}-67$ and PCNA.

Several studies showed that B7-H3 had a nonimmunological role in cancer progression. It could promote tumor invasion and metastasis, such as in cutaneous melanoma, osteosarcoma, and non-small-cell lung cancer. ${ }^{24,25,29} \mathrm{We}$ found that the migratory rate of U937 cells was decreased more than fivefold in the B7-H3 knockdown group, whereas the cell matrix invasive capacity was reduced by $86.7 \%$, compared to the NC group. Since MMP-2 and MMP-9 are 

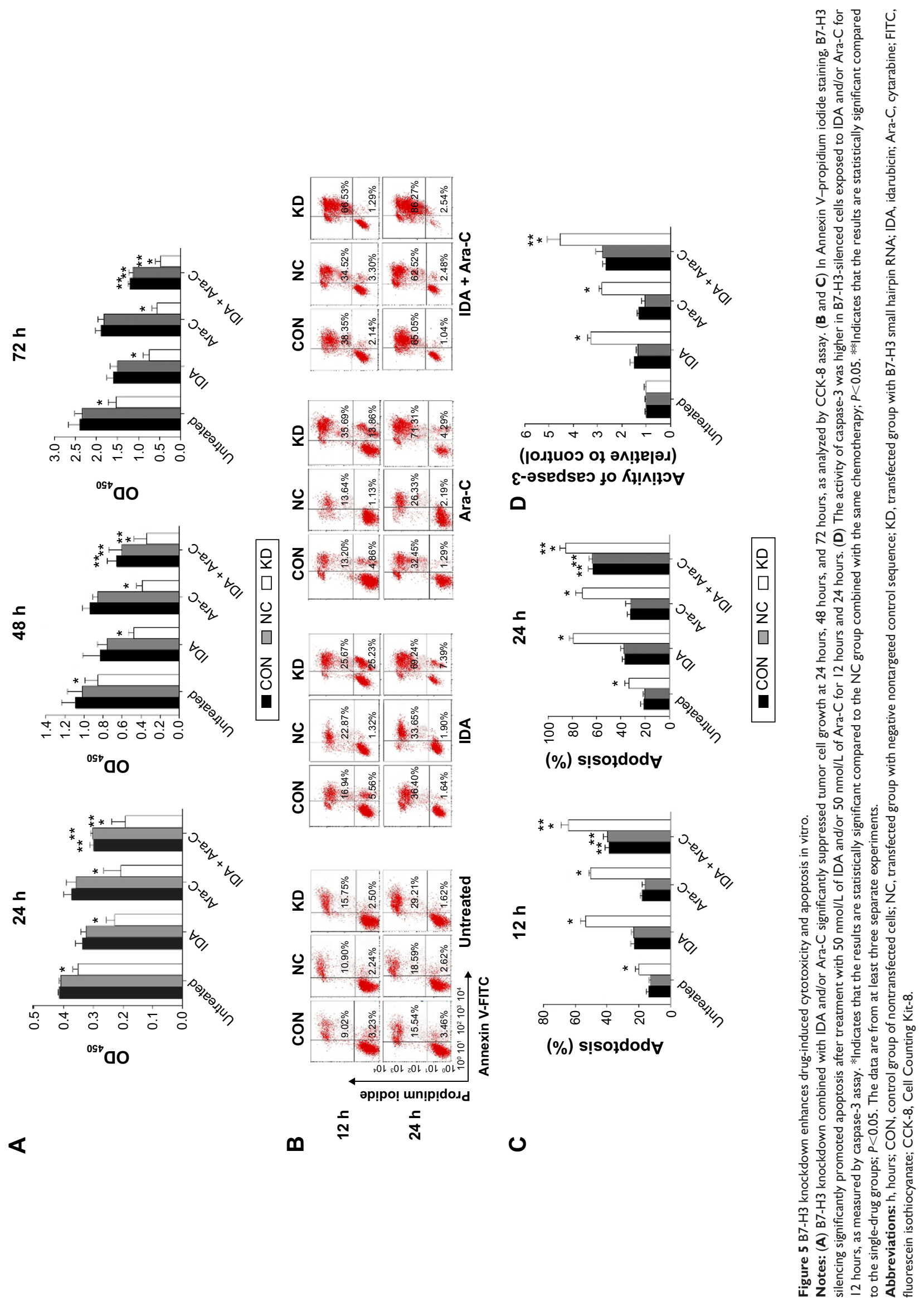

$\varangle$

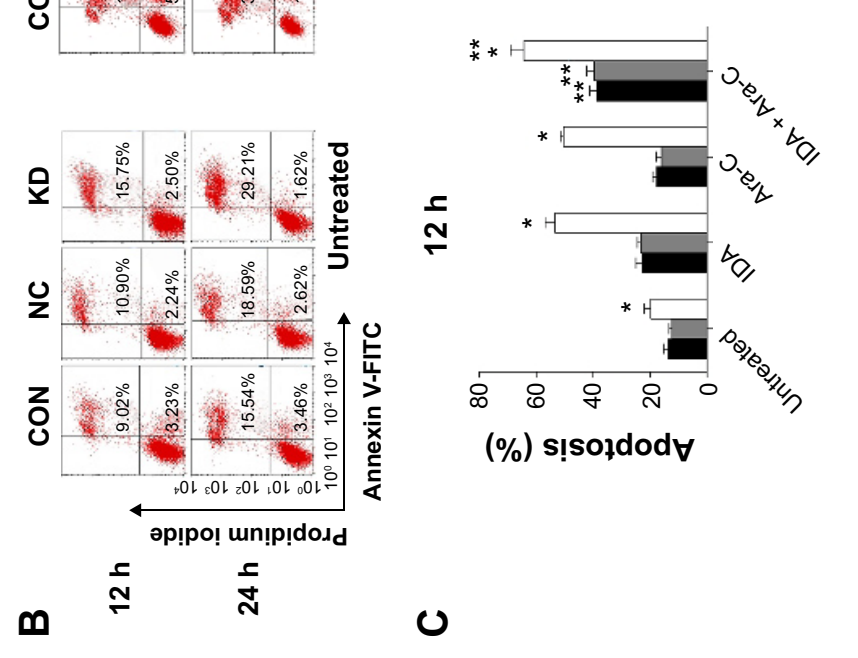




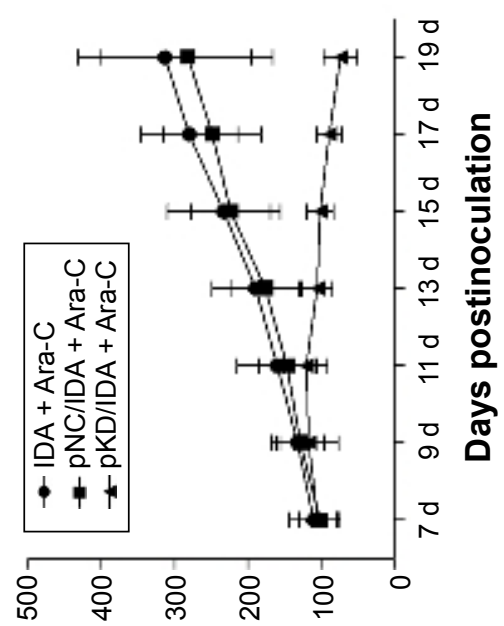

( $\left.{ }_{\varepsilon} \mathrm{mu}\right)$ əun

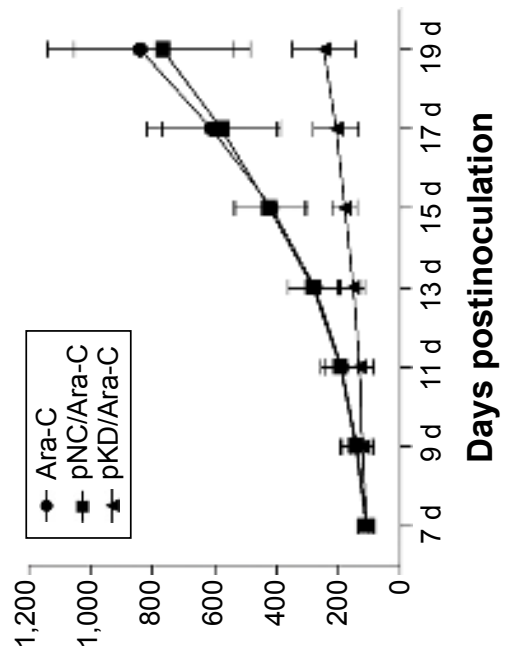

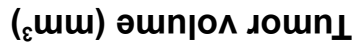

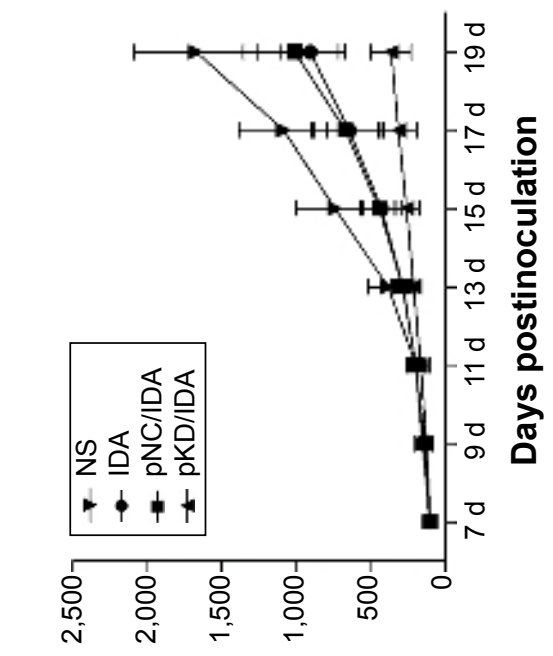

$\varangle \quad\left({ }_{\varepsilon} m u\right)$ əun

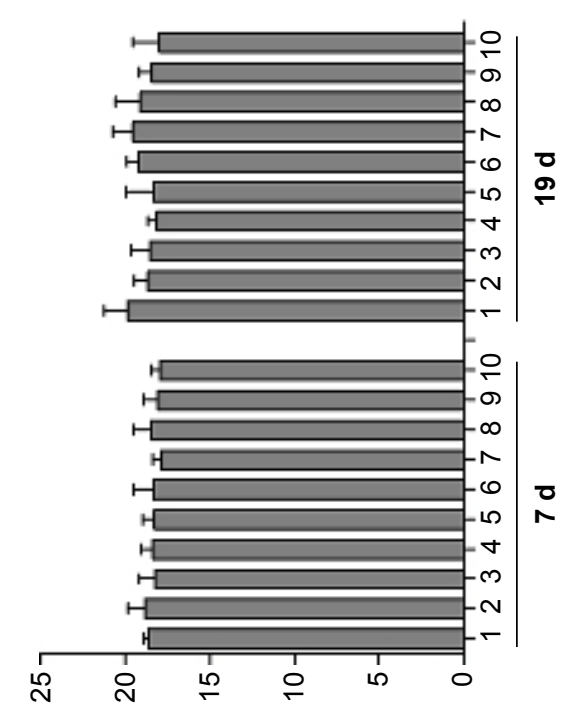

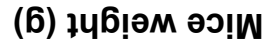
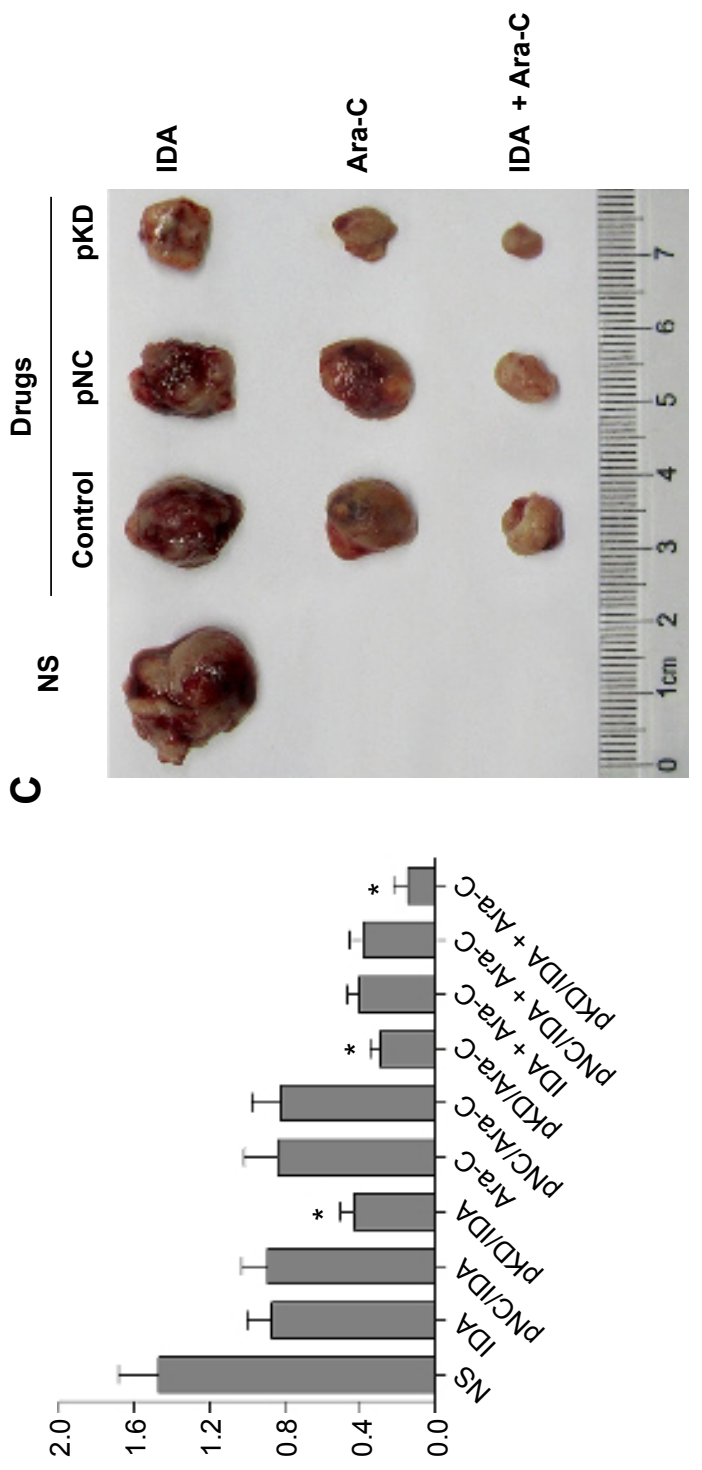

m (6) Ұч6!əм Joun $\perp$

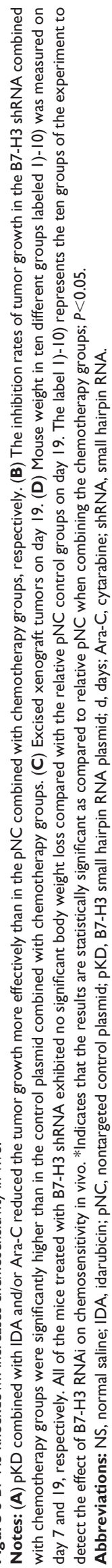


proteolytic enzymes involved in tumor cell migration, invasion, and metastasis, ${ }^{30}$ we measured the mRNA expression of both MMPs by RT-PCR. The expression of both MMPs apparently decreased in B7-H3-silenced U937 cells, and a similar MMP-2 result has previously been shown in B7-H3 knockdown melanoma cells. ${ }^{23}$ The results suggest that B7-H3 is involved in the transcriptional regulation of the $M M P-2$ and $M M P-9$ genes, resulting in the increased invasion of U937 cells.

Recently, the standard induction regimens for AML M5 consult that used in AML patients younger than 60 years, as recommended by the National Comprehensive Cancer Network clinical practice guidelines, with Ara-C and an anthracycline, such as IDA. IDA, as an anthracycline antibiotic, is known to induce double-stranded DNA breaks, while the important antimetabolite Ara-C has an impact on DNA replication; they both exert cytotoxic effects including the induction of apoptosis. ${ }^{31,32}$ Although progress has been made, the outcome of AML M5 is unsatisfactory. In this study, we first observed the cytotoxic effect and apoptosis induced by IDA and/or Ara-C in U937 cells, and the results confirmed that silencing of B7-H3 increases chemosensitivity in both the single-drug and two-drug combination groups. The synergistic cell apoptotic effects in U937 cells induced by the IDA and Ara-C combination were promoted by B7-H3 knockdown in a time-dependent manner. A similar study was performed in B7-H3-silenced breast cancer cells, in which increased cell line sensitivity to paclitaxel as a result of enhanced drug-induced apoptosis was observed. ${ }^{28}$ In apoptosis signaling cascades, two different initiation machineries, the extrinsic death receptormediated signaling, and intrinsic caspase family cysteine protease-mediated signaling play major roles in a variety of cell types. ${ }^{33,34}$ We reconfirmed that the effector caspase of the mitochondrial downstream caspase-3 plays a critical role in U937 cell apoptosis induced by IDA and/or Ara-C, and that the activity of caspase-3 in the two-drug combination B7-H3 knockdown group was the most significantly increased by $63.3 \%$ compared to the NC group. The data indicate that the blockade of B7-H3 may significantly increase the therapeutic efficacy in vitro. A recent study also proved that B7-H3 overexpression inhibited apoptosis in colorectal cancer cell lines, accompanied by the downregulation of active caspase- $3 .{ }^{35}$

In recent years, the nonimmunological role of $\mathrm{B} 7-\mathrm{H} 3$ in the enhancement of the sensitivity of cancer cells to chemotherapeutic compounds has received increasing attention. ${ }^{36}$ In our study, we treated the U937 xenograft model with a B7-H3 shRNA plasmid combined with IDA and/or Ara-C, and found that the rates of tumor growth inhibition were dramatically higher than in the relative $\mathrm{pNC}$ combined with chemotherapy groups. At the end of the observation period, the rate of tumor growth inhibition reached $90.0 \%$ in the B7-H3 shRNA combined with two drugs group. Our findings in vivo demonstrated that silencing B7-H3 apparently enhanced the sensitivity to first-line chemotherapy drugs of AML M5 U937 xenografts. Moreover, we found in another study that the treatment using the same plasmid of B7-H3 shRNA combined with other chemotherapy drugs dramatically inhibited the growth of mantle cell lymphoma Maver and Z138 xenografts by $92.3 \%$ and $92.9 \%$, respectively. ${ }^{27}$ Similarly, previous studies have also reported that B7-H3 may promote cancer resistance to drug treatments in breast cancer and pancreatic carcinoma xenograft models. ${ }^{28,37}$

Although B7-H3 is a type I transmembrane protein, we find that its protein is also highly expressed in the nuclei and cytoplasm of AML M5 U937 cells, with a similar subcellular distribution as colorectal cancer, detected by immunohistochemical analysis. ${ }^{7}$ Then, we confirmed that B7-H3 knockdown is performed by RNAi technology in protein subcellular distribution of nuclei and cytoplasm, and membrane, and it inhibits tumor proliferation, cell cycle progression, migration, and invasion, thus increasing drug-induced apoptosis and enhancing therapeutic efficacy. Therefore, further investigations should be performed to explore the effects and the exact signaling pathways of different subcellular localizations of B7-H3 on the oncogenesis and chemosensitivity of U937 cells.

\section{Conclusion}

In order to rule out unspecific effects, we used the same recombinant lentivirus-mediated $\mathrm{B} 7-\mathrm{H} 3$ knockdown in mantle cell lymphoma Maver and Z138 cell lines in another study, and also made the conclusion that B7-H3 promotes mantle cell lymphoma progression and that targeting B7-H3 knockdown significantly enhances the chemosensitivity in vitro and in vivo. ${ }^{27}$ This indicates that $\mathrm{B} 7-\mathrm{H} 3$ promotes tumor progression in a series of hematologic malignancies, and that B7-H3 silencing enhances chemosensitivity, though not only in U937 cells. The strategy of targeting B7-H3 may provide a new therapeutic approach to hematologic malignancies, such as in AML M5.

\section{Acknowledgments}

We are very grateful to Dr Chen Huang of Key Laboratory of Peking University Third Hospital for assistance. This work was supported by a grant from the National Natural Science Foundation of China (81172245). 


\section{Disclosure}

The authors report no conflicts of interest in this work.

\section{References}

1. Yu H, Li Y, Gao C, et al. Relevant mouse model for human monocytic leukemia through Cre/lox-controlled myeloid-specific deletion of PTEN. Leukemia. 2010;24(5):1077-1080.

2. Tallman MS, Kim HT, Paietta E, et al; Eastern Cooperative Oncology Group. Acute monocytic leukemia (French-American-British classification M5) does not have a worse prognosis than other subtypes of acute myeloid leukemia: a report from the Eastern Cooperative Oncology Group. J Clin Oncol. 2004;22(7):1276-1286.

3. Baer MR, Stewart CC, Lawrence D, et al. Acute myeloid leukemia with 11q23 translocations: myelomonocytic immunophenotype by multiparameter flow cytometry. Leukemia. 1998;12(3):317-325.

4. Chapoval AI, Ni J, Lau JS, et al. B7-H3: a costimulatory molecule for T cell activation and IFN-gamma production. Nat Immunol. 2001;2(3): 269-274.

5. Luo L, Chapoval AI, Flies DB, et al. B7-H3 enhances tumor immunity in vivo by costimulating rapid clonal expansion of antigen-specific $\mathrm{CD} 8^{+}$ cytolytic T cells. J Immunol. 2004;173(9):5445-5450.

6. Xu H, Cheung IY, Guo HF, Cheung NK. MicroRNA miR-29 modulates expression of immunoinhibitory molecule B7-H3: potential implications for immune based therapy of human solid tumors. Cancer Res. 2009;69(15):6275-6281.

7. Ingebrigtsen VA, Boye K, Tekle C, Nesland JM, Flatmark K, Fodstad O. B7-H3 expression in colorectal cancer: nuclear localization strongly predicts poor outcome in colon cancer. Int J Cancer. 2012;131(11): 2528-2536.

8. Sun TW, Gao Q, Qiu SJ, et al. B7-H3 is expressed in human hepatocellular carcinoma and is associated with tumor aggressiveness and postoperative recurrence. Cancer Immunol Immunother. 2012;61(11): 2171-2182.

9. Chen C, Shen Y, Qu QX, Chen XQ, Zhang XG, Huang JA. Induced expression of $\mathrm{B} 7-\mathrm{H} 3$ on the lung cancer cells and macrophages suppresses T-cell mediating anti-tumor immune response. Exp Cell Res. 2013; 319(1):96-102.

10. Yamato I, Sho M, Nomi T, et al. Clinical importance of B7-H3 expression in human pancreatic cancer. Br J Cancer. 2009;101(10):1709-1716.

11. Arigami T, Narita N, Mizuno R, et al. B7-h3 ligand expression by primary breast cancer and associated with regional nodal metastasis. Ann Surg. 2010;252(6):1044-1051.

12. Hu Y, Lv X, Wu Y, et al. Expression of costimulatory molecule B7-H3 and its prognostic implications in human acute leukemia. Hematology. 2015;20(4):187-195

13. Guéry T, Roumier C, Berthon C, et al. The B7-H3 protein in acute myeloid leukemia. Blood. 2013;122(21):2620.

14. Zhao DD, Lin L, Ge Q, et al. [Relation of B7-H3 molecule expression in multiple myeloma with poor prognosis and bone destruction]. Zhongguo Shi Yan Xue Ye Xue Za Zhi. 2013;21(3):637-642. Chinese.

15. Sun X, Vale M, Leung E, Kanwar JR, Gupta R, Krissansen GW. Mouse B7-H3 induces antitumor immunity. Gene Ther. 2003;10(20): $1728-1734$.

16. Suh WK, Gajewska BU, Okada H, et al. The B7 family member B7-H3 preferentially down-regulates $\mathrm{T}$ helper type 1-mediated immune responses. Nat Immunol. 2003;4(9):899-906.

OncoTargets and Therapy

\section{Publish your work in this journal}

OncoTargets and Therapy is an international, peer-reviewed, open access journal focusing on the pathological basis of all cancers, potential targets for therapy and treatment protocols employed to improve the management of cancer patients. The journal also focuses on the impact of management programs and new therapeutic agents and protocols on
17. Leitner J, Klauser C, Pickl WF, et al. B7-H3 is a potent inhibitor of human T-cell activation: No evidence for B7-H3 and TREML2 interaction. Eur J Immunol. 2009;39(7):1754-1764.

18. Brunner A, Hinterholzer S, Riss P, Heinze G, Brustmann H. Immunoexpression of B7-H3 in endometrial cancer: relation to tumor T-cell infiltration and prognosis. Gynecol Oncol. 2012;124(1):105-111.

19. Chen YW, Tekle C, Fodstad O. The immunoregulatory protein human $\mathrm{B} 7 \mathrm{H} 3$ is a tumor-associated antigen that regulates tumor cell migration and invasion. Curr Cancer Drug Targets. 2008;8(5):404-413.

20. Zhao X, Li DC, Zhu XG, et al. B7-H3 overexpression in pancreatic cancer promotes tumor progression. Int J Mol Med. 2013;31(2):283-291.

21. Yuan H, Wei X, Zhang G, Li C, Zhang X, Hou J. B7-H3 over expression in prostate cancer promotes tumor cell progression. J Urol. 2011; 186(3):1093-1099.

22. Lemke D, Pfenning PN, Sahm F, et al. Costimulatory protein 4IgB7H3 drives the malignant phenotype of glioblastoma by mediating immune escape and invasiveness. Clin Cancer Res. 2012;18(1):105-117.

23. Tekle C, Nygren MK, Chen YW, et al. B7-H3 contributes to the metastatic capacity of melanoma cells by modulation of known metastasisassociated genes. Int $J$ Cancer. 2012;130(10):2282-2290.

24. Wang J, Chong KK, Nakamura Y, et al. B7-H3 associated with tumor progression and epigenetic regulatory activity in cutaneous melanoma. J Invest Dermatol. 2013;133(8):2050-2058.

25. Wang L, Zhang Q, Chen W, et al. B7-H3 is overexpressed in patients suffering osteosarcoma and associated with tumor aggressiveness and metastasis. PLoS One. 2013;8(8):e70689.

26. Li Y, Wang J, Li C, Ke XY. Contribution of PD-L1 to oncogenesis of lymphoma and its RNAi-based targeting therapy. Leuk Lymphoma. 2012; 53(10):2015-2023.

27. Zhang $\mathrm{W}$, Wang $\mathrm{Y}$, Wang J, et al. B7-H3 silencing inhibits tumor progression of mantle cell lymphoma and enhances chemosensitivity. Int J Oncol. 2015;46(6):2562-2572.

28. Liu H, Tekle C, Chen YW, et al. B7-H3 silencing increases paclitaxel sensitivity by abrogating Jak2/Stat 3 phosphorylation. Mol Cancer Ther. 2011;10(6):960-971.

29. Sun Y, Wang Y, Zhao J, et al. B7-H3 and B7-H4 expression in nonsmall-cell lung cancer. Lung Cancer. 2006;53(2):143-151.

30. Shapiro SD. Matrix metalloproteinase degradation of extracellular matrix: biological consequences. Curr Opin Cell Biol. 1998;10(5):602-608.

31. Liu FT, Kelsey SM, Newland AC, Jia L. Generation of reactive oxygen species is not involved in idarubicin-induced apoptosis in human leukaemic cells. Br J Haematol. 2001;115(4):817-825.

32. Iacobini M, Menichelli A, Palumbo G, Multari G, Werner B, Del Principe D. Involvement of oxygen radicals in cytarabine-induced apoptosis in human polymorphonuclear cells. Biochem Pharmacol. 2001; 61(8):1033-1040.

33. Cryns V, Yuan J. Proteases to die for. Genes Dev. 1998;12(11):1551-1570.

34. Thornberry NA, Lazebnik Y. Caspases: enemies within. Science. 1998; 281(5381):1312-1316.

35. Zhang T, Jiang B, Zou ST, Liu F, Hua D. Overexpression of B7-H3 augments anti-apoptosis of colorectal cancer cells by Jak2-STAT3. World J Gastroenterol. 2015;21(6):1804-1813.

36. Wang L, Kang FB, Shan BE. B7-H3-mediated tumor immunology: Friend or foe? Int J Cancer. 2014;134(12):2764-2771.

37. Zhao X, Zhang GB, Gan WJ, et al. Silencing of B7-H3 increases gemcitabine sensitivity by promoting apoptosis in pancreatic carcinoma. Oncol Lett. 2013;5(3):805-812.

\section{Dovepress}

patient perspectives such as quality of life, adherence and satisfaction. The manuscript management system is completely online and includes a very quick and fair peer-review system, which is all easy to use. Visit http://www.dovepress.com/testimonials.php to read real quotes from published authors. 